\title{
A STUDY TO DETERMINE THE CONTRIBUTING FACTORS FOR ICU STRESS AND TO ASSESS THE EFFECTIVENESS OF INTERVENTION PACKAGE IN REDUCING STRESS AMONG PATIENTS ADMITTED IN ICU
}

\section{DR. K. PRISCILLA}

Professor, Medical Surgical Nursing, C.S.I. Jeyaraj Annapakiam College of Nursing, Madurai, Tamil Nadu, India

\section{ABSTRACT}

The experience of an ICU is extremely stressful and disruptive for patients and family members. The environmental factors have affected the safety, patient outcome in ICU. Survivors of critical illness face a prolonged period of recovery due to physical weakness, malnutrition, breathlessness, lot of muscle mass and cognitive dysfunction. The Physical Environment such as noise, constant light, Sensory overload is implicated in ICU syndrome. Tactile touch therapy is the practice of massage which include Physical and Psychological outcome of the client. Psychoacoustic therapy is a Powerful distracter from distressful sounds and thoughts in the ICU. The Present study is aimed to determine the contributing factors for ICU stress and to assess the effectiveness of intervention package in reducing stress among patients admitted in ICU.A quasi experimental study with control group pretest and posttest design was adopted. A total of 200 samples admitted in ICU were selected. Convenience sampling technique was used. Contributing factors for ICU stress was assessed by Environmental Stressor Questionnaire(ESQ).The stressor identified were interpersonal, extra personal, and intrapersonal factors both in control and intervention group. Interpersonal factors $(88 \% \& 87.5 \%)$ contributed. More than the Extra personal(86\%\&86.5\%)and Intrapersonal factors(84.7\%\&84.7\%).Psycho acoustic therapy along with Tactile touch therapy were administered to intervention group for five days. Level of stress was assessed by Modified Stress scale. The result revealed that majority of the samples had high level stress in intervention group(54\%)and control group(51\%).After the intervention. Overall post test mean score of stress in experimental group is 38.14 (SD 7.54) the t value is 30.78 which is statistically significant at 0.05 level.

KEYWORDS: Stress, Psycho Acoustic Therapy, Tactile Touch Therapy \& I C U

Received: Mar 16, 2021; Accepted: Apr 06, 2021; Published: May 13, 2021; Paper Id.: IJMPSJUN202110

\section{INTRODUCTION}

Intensive care unit is a place where patients with critical condition need special care and treatment. Roger Ulrich has described that the ICU setting is a sterile and bare as a cold garage and the patients have the feeling of hearing frightening sounds, fear of death, feeling of loneliness and insecurity about concrete matters happen because the technical equipment's are the dominating factors. Patients in intensive care unit face multiple stressors so they are critically ill, subject to pain and need pharmaceutical support for failing in vital organs. Intensive care units backgrounds are extremely stressful situation that results from emergencies, high technological complexity environment and the basis of an emotionally risky scenario both for the patients and their family members. Many authors have identified that the physical environment is a contributing factors for ICU stress.

Measurement of patients out come at regular interval is necessary to identify problems and guide the nurses to select intervention which helps to promote sleep, nutrition and wellbeing. Complementary and alternative 
medicine (CAM) is not expensive, holistic and free from side effects. Massage is considered as medical therapy when the focus of care moves to biological science. Sound vibration directly aligns all energy field sound and music is used to move the attention away from an unwanted and unpleasant situation. The investigator has found that even though with the availability of beneficial complementary therapies they are not used as a nursing intervention in clinical setup. Hence the researcher would like to identify the effectiveness of psychoacoustic therapy and tactile touch therapy on stress in ICU patients.

\section{Statement of the Problem}

A study to determine the contributing factors for ICU stress and to assess the effectiveness of intervention package in reducing stress among patients admitted in ICU.

\section{Objectives}

- To find out the contributing factors for stress among patients admitted in ICU

- To assess the pretest and posttest level of stress among patients admitted in ICU in the experimental and control group.

- To evaluate the effectiveness of intervention package on stress among patients admitted in ICU

- To find out the association between level of stress in experimental group of patients with their selected demographic variables and clinical characteristics

\section{Hypothesis}

- The mean posttest level of stress among experimental group of patients in ICU will be significantly lower than the mean pretest level of stress

- The mean posttest level of stress among experimental group of patients in ICU will be significantly lower than the mean posttest level of stress among control group

- There will be a significant association between posttest level of stress in experimental group of patients in ICU and their selected demographic variables and clinical characteristics.

\section{METHODOLOGY}

\section{Research Approach}

Research approach used for this study is quantitative approach

\section{Research Design}

Quasi experimental prêt test, post test control group design was used.

\begin{tabular}{|l|c|c|c|}
\hline \multicolumn{1}{|c|}{ Group } & $\begin{array}{c}\text { Measurement of dep. } \\
\text { Variables }\end{array}$ & $\begin{array}{c}\text { Manipulation of independent } \\
\text { variables }\end{array}$ & $\begin{array}{c}\text { Measurement of dependent Variable } \\
\text { on 6 }^{\text {th }} \text { day }\end{array}$ \\
\hline Exp. Group & $0_{1}$ & $\mathrm{X}$ & $0_{2}$ \\
\hline $\begin{array}{l}\text { Control } \\
\text { group }\end{array}$ & $0_{1}$ & --- & $0_{2}$ \\
\hline
\end{tabular}




\section{Variables}

- Independent variables

- Dependent variables

- Extraneous variables

\section{Setting of the Study}

The setting of this present study includes Devadoss Multispeciality Hospital and Madurai Institute of Traumatology (MIOT) Madurai.

\section{Accessible Population}

Patients who were admitted in ICU of Devadoss Multi-speciality Hospital and Madurai Institute of Traumatology (MIOT) Madurai.

\section{Sample}

Patients who fulfilled the inclusion and exclusion criteria were selected as samples

\section{Sample Size}

Based on power analysis the required sample size is 85 in each group, but the investigator took 100samples in experimental and control group.

\section{Sampling Technique}

Non probability purposive sampling technique was used.

\section{Description of the Tool}

Part I - Demographic Variables

- $\quad$ Part II - Modified Environmental Stressors Questionnaire (ESQ)

- $\quad$ Part III - Modified stress scale.

\section{Modified Environmental Stressor Questionnaire}

It include 20 items, which include intra personal factors (16 items) Inter personal factors (18 items) and extra personal factors (16 items)

\section{Scoring}

For each item the mean \% was worked out (actual score/ Maximum possible score X 100) and arranged according to the mean value by providing ranking.

\section{Modified Stress Scale}

- It consists of 29 statements which include

- physical factors 12 statements 
- $\quad$ psychological factors 12 statements

- $\quad$ social factors 5 statements

\section{Scoring}

- Low level stress

$0-33 \%$

- Moderate level stress

- $\quad$ High level stress

$68 \%-100 \%$

\section{Development of an Intevention Package}

- Tactile touch therapy. The investigator has undergone certified training under an expert at Valliammal Instiute Madurai. The techniques involve are effleurage, pertisage, percussion and friction

- Psychoacoustic therapy. The Music is composed and based on Karnatic and Raga Hemendra Madyama. The music is integrated with natural sounds such as river, water, waves, rain and birds.

\section{Testing of the Tool}

\section{Validity}

The instruments were given to 13 experts in the field of medicine, nursing, yoga, etc....

\section{Reliability}

\begin{tabular}{|l|l|c|c|c|c|}
\hline S.No & \multicolumn{1}{|c|}{ Tool } & No.of Items & N & Alpha Reliability & Validity \\
1. & $\begin{array}{l}\text { Modified Environmental } \\
\text { Stressor Questionnaire } \\
\text { (ESQ) }\end{array}$ & 50 & 200 & 0.810 & 0.900 \\
\hline 2. & Modified stress scale & 29 & 400 & 0.827 & 0.909 \\
\hline
\end{tabular}

\section{Method of Data Collection}

Formal permission was obtained from concerned authority at Sacred Heart Nursing College \& obtained consent from the Hospital authorities. Each day 2-4. Samples were selected assessed the contributing factors for ICU stress was assessed by modified ESQ. Pretest assessment of stress was done by modified stress scale. Intervention package were administrated for $1,2,3,4,5^{\text {th }}$ days. Post test assessment was done on $6^{\text {th }}$ day.

\section{Data Analysis \& Interpretation}

The data obtained are tabulated, analysed and interpreted using descriptive and inferential statistics based on the objective and hypothesis formulated for the study.

Table 1: Ranking Order for the Stressors in Experimental Group and Control Group of Patients Admitted in ICU N=200

\begin{tabular}{|l|c|l|}
\hline \multicolumn{1}{|c|}{ Experimental Group } & $\begin{array}{c}\text { Ranking } \\
\text { Order }\end{array}$ & \multicolumn{1}{c|}{ Control Group } \\
\hline $\begin{array}{c}\text { Observing treatment being administered to other } \\
\text { patients (Interpersonal factor) }\end{array}$ & 1 & $\begin{array}{l}\text { Observing treatment being administered to } \\
\text { other patients (Interpersonal factor) }\end{array}$ \\
\hline $\begin{array}{c}\text { Not knowing exactly where you are (extra } \\
\text { personal factors) }\end{array}$ & 2 & $\begin{array}{l}\text { Not knowing exactly where you are (Extra } \\
\text { personal factor) }\end{array}$ \\
\hline
\end{tabular}




\begin{tabular}{|l|c|l|}
\hline $\begin{array}{l}\text { Nactor) } \\
\text { factor) }\end{array}$ & 3 & $\begin{array}{l}\text { Not knowing what time it is (Extra personal } \\
\text { factor) }\end{array}$ \\
\hline $\begin{array}{l}* \\
\text { factor) }\end{array}$ & 4 & $\begin{array}{l}\text { Listening to the telephone ringing (Extra } \\
\text { personal factor) }\end{array}$ \\
\hline $\begin{array}{l}\text { Don't know the doctors who cares you(Inter } \\
\text { personal factor) }\end{array}$ & 6 & $\begin{array}{l}\text { Missing your spouse or partners (Inter } \\
\text { personal factor) }\end{array}$ \\
\hline $\begin{array}{c}\text { Having men and women in same room (Inter } \\
\text { personal factor) }\end{array}$ & 7 & Having to use oxygen (Extra personal factor) \\
\hline $\begin{array}{c}\text { Not receiving adequate explanation about the } \\
\text { treatment and procedure (Inter personal factor) }\end{array}$ & 8 & $\begin{array}{l}\text { Not having to use oxygen (Inter personal } \\
\text { factor) }\end{array}$ \\
\hline Having to use oxygen (Extra personal factor) & 9 & $\begin{array}{l}\text { Having men and women in same room (Inter } \\
\text { personal factor) }\end{array}$ \\
\hline
\end{tabular}

Table 1: Presents the top ten ranks for the stressors in experimental and control group. The stressors in top ten rank include interpersonal, extra personal and intra personal factors. Interpersonal factors and extra personal factors ranked from first to fifth which are observing treatment being administered to other patients, not knowing exactly where you are, not knowing what time it is, listening to telephone ringing, missing your spouse or partner, not able to eat.

Table 2: Comparison of Dimension of Stressors in Experimental Group and Control Group of Patients Admitted in ICU N=200

\begin{tabular}{|l|c|c|c|c|c|}
\hline \multirow{2}{*}{ Stressors } & \multicolumn{2}{|c|}{ Experimental Group } & \multicolumn{2}{c|}{ Control Group } & \multirow{2}{*}{ 't' Value } \\
\cline { 2 - 5 } Intra personal factors & Mean & SD & Mean & SD & ( \\
\hline Inter personal factors & 84.73 & 4.63 & 84.70 & 4.56 & $\begin{array}{c}0.48 \\
\mathrm{P}>0.05 \\
\mathrm{NS}\end{array}$ \\
\hline Extra personal factors & 88.27 & 3.96 & 87.55 & 3.22 & $\begin{array}{c}1.413 \\
\mathrm{P}>0.05 \\
\mathrm{NS}\end{array}$ \\
\hline & 86.20 & 3.44 & 86.59 & 3.78 & $\begin{array}{c}0.763 \\
\mathrm{P}>0.05 \\
\mathrm{NS}\end{array}$ \\
\hline
\end{tabular}

$\mathrm{P}>0.05$

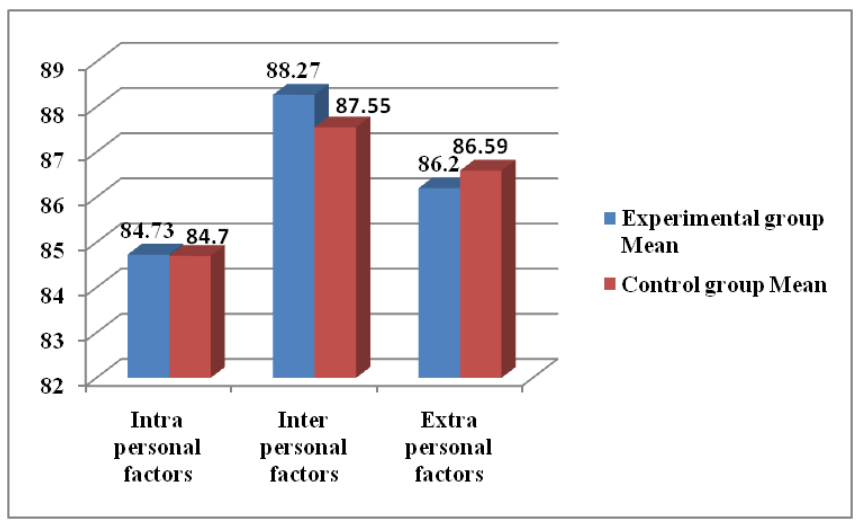

Figuer 1

Table 2: reveals that the intra personal, inter personal and extra personal factors are equally contributed towards ICU stress in both the experimental and control group since the obtained 't' value is not significant at 0.05 level . 
Table 3: Distribution of Samples based on Level of Stress in the Experimental and Control Group of Patients Admitted in ICU N=200

\begin{tabular}{|c|c|c|c|c|c|c|c|c|}
\hline \multirow{2}{*}{ Level of Stress } & \multicolumn{2}{|c|}{ Experimental Group } & \multicolumn{3}{|c|}{ Control Group } \\
\cline { 2 - 10 } & \multicolumn{2}{|c|}{ Pre test } & \multicolumn{2}{|c|}{ Post Test } & \multicolumn{2}{|c|}{ Pre Test } & \multicolumn{2}{c|}{$\begin{array}{c}\text { Post } \\
\text { Test }\end{array}$} \\
\cline { 2 - 10 } & F & \% & F & $\%$ & F & \% & F & \% \\
\hline Low level & 10 & 10 & 49 & 49 & 12 & 12 & 14 & 14 \\
\hline Moderate level & 36 & 36 & 51 & 51 & 37 & 37 & 38 & 38 \\
\hline High level & 54 & 54 & 0 & 0 & 51 & 51 & 48 & 48 \\
\hline
\end{tabular}

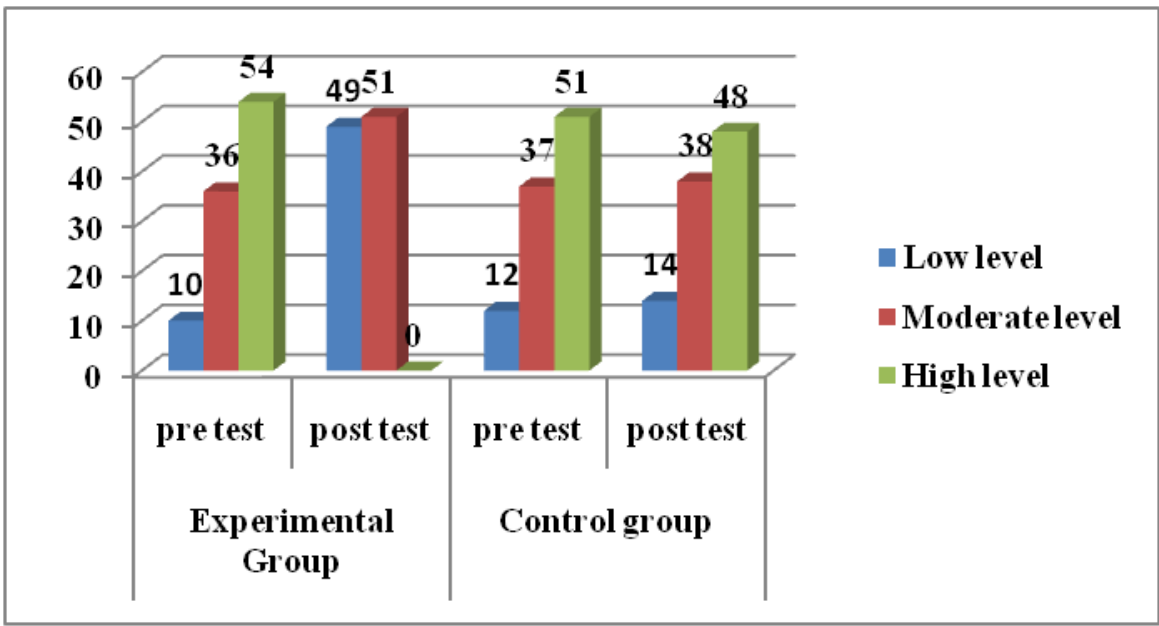

Figure 2

The above bar diagram revealed that in pre test majority of the samples have high level of stress in the experimental and control group. However in experimental group during post test 49 (49\%) samples have low level stress \& $51(51 \%)$ samples have moderate level stress. No sample has found to have high level stress.

In control group post test nearly half of the samples 48 (48\%) have high level stress $38(38 \%)$ samples have moderate level stress and only 14 (14\%) samples found to have low level stress.

Table 4: Comparison Of Pre Test And Post Test Mean Scores Of Stress In Experimental Group Of Patients Admitted In ICU. $\mathrm{N}=100$

\begin{tabular}{|c|c|c|c|c|c|c|c|c|}
\hline \multirow{3}{*}{ S. No. } & \multirow{3}{*}{$\begin{array}{c}\text { Dimension } \\
\text { of Stress }\end{array}$} & \multicolumn{4}{|c|}{ Experimental } & \multirow{3}{*}{$\begin{array}{c}\text { Mean Difference } \\
\text { Mean } \\
\end{array}$} & \multirow{3}{*}{$\begin{array}{c}\text { 'T' Value } \\
\text { SD } \\
\end{array}$} & \multirow{3}{*}{$\begin{array}{l}\text { P Value } \\
P<0.001\end{array}$} \\
\hline & & \multicolumn{2}{|c|}{ Pre Test } & \multicolumn{2}{|c|}{ Post Test } & & & \\
\hline & & Mean & SD & Mean & SD & & & \\
\hline 1. & Physical factors & 56.97 & 13.94 & 31.33 & 11.95 & 25.645 & 13.24 & $\mathrm{P}<0.001$ \\
\hline 2. & Psychological factors & 86.25 & 4.77 & 38.10 & 10.33 & 48.145 & 41.596 & $\mathrm{P}<0.001$ \\
\hline 3. & Social factors & 55.70 & 8.73 & 45.00 & 8.07 & 10.700 & 9.284 & $\mathrm{P}<0.001$ \\
\hline 4. & Over all & 66.30 & 4.95 & 38.14 & 7.54 & 28.16 & 28.86 & $\mathrm{P}<0.001$ \\
\hline
\end{tabular}
$\mathrm{P}<0.001 * * *$

Table 4 denotes that there is significant difference between pre test and post test level of stress in experimental group. The mean difference is found to be higher for the psychological factor (48.14) than the physical (25.64) and social factor (10.70) and the ' $\mathrm{t}$ ' value is significant at $\mathrm{P}<0.001$ level. So it is concluded that the intervention was effective in experimental group 
Table 5: Comparison of Post Test Mean Scores of Stress between Experimental and Control Group of Patients Admitted in ICU N=200

\begin{tabular}{|l|l|c|c|c|c|c|c|c|}
\hline \multirow{2}{*}{ S. No. } & \multirow{2}{*}{ Dimension of Stress } & \multicolumn{2}{|c|}{$\begin{array}{c}\text { Exp.Group } \\
\text { Post Test }\end{array}$} & \multicolumn{2}{c|}{$\begin{array}{c}\text { Control Group } \\
\text { Post Test }\end{array}$} & Mean Difference & 't' Value & P Value \\
\cline { 3 - 9 } & & Mean & SD & Mean & SD & Mean & SD & P $<\mathbf{0 . 0 5}$ \\
\hline 1. & Physical factors & 31.33 & 11.95 & 55.29 & 11.87 & 23.95 & 14.21 & $\mathrm{P}<0.05$ \\
\hline 2. & Psychological factors & 38.10 & 10.33 & 85.93 & 4.83 & 47.83 & 41.92 & $\mathrm{P}<0.05$ \\
\hline 3. & Social factors & 45.0 & 8.07 & 54.85 & 9.54 & 9.85 & 7.87 & $\mathrm{P}<0.05$ \\
\hline 4. & Over all & 38.14 & 7.54 & 65.33 & 4.611 & 27.21 & 30.78 & $\mathrm{P}<0.05$ \\
\hline $\mathrm{P}<0.05 * * *$
\end{tabular}

The above figure revealed, that there is a significant difference between post test mean score of physical, psychological, and social factors between experimental and control group since the obtained ' $t$ ' values are significant at $\mathrm{P}<0.05$ level.

Table 6: Item Wise Comparison of Post Test Mean Scores of Stress in Experimental and Control Group of Patients Admitted in ICU N=200

\begin{tabular}{|c|c|c|c|c|c|c|}
\hline \multirow[t]{2}{*}{ Item No. } & \multirow[t]{2}{*}{ Items of Stress } & \multicolumn{2}{|c|}{$\begin{array}{l}\text { Exp.group } \\
\text { Post Test }\end{array}$} & \multicolumn{2}{|c|}{$\begin{array}{c}\text { Control Group } \\
\text { Post Test }\end{array}$} & \multirow[t]{2}{*}{ 't' Value } \\
\hline & & Mean & SD & Mean & SD & \\
\hline 4 & Feeling nervous when left alone & 1.94 & .239 & 3.53 & .502 & $\begin{array}{c}28.62 \\
(p<0.01)\end{array}$ \\
\hline 6 & Find it difficult to tolerate the interruption of sleep & 1.26 & .630 & 3.02 & .738 & $\begin{array}{c}18.139 \\
(\mathrm{p}<0.01)\end{array}$ \\
\hline 7 & Having an uncomfortable feeling like butterflies in the stomach & 1.55 & .770 & 2.60 & 1.06 & $\begin{array}{c}7.99 \\
(p<0.01)\end{array}$ \\
\hline 15 & Night mares & 1.58 & .684 & 3.79 & .409 & $\begin{array}{c}27.715 \\
(\mathrm{p}<0.01)\end{array}$ \\
\hline 23 & Spells of terror and panic & 1.51 & .759 & 3.31 & .692 & $\begin{array}{c}17.53 \\
(p<0.01)\end{array}$ \\
\hline 29 & Feel anxious due to financial crisis & 1.25 & .435 & 3.26 & .613 & $\begin{array}{c}26.728 \\
(\mathrm{p}<0.01)\end{array}$ \\
\hline
\end{tabular}

The above findings revealed that there is significant difference between post test mean score of various items of stress in the experimental and control groups since the ' $\mathrm{t}$ ' value for the each component is significant at $\mathrm{P}<0.01$ * level.

Table 7: Association between Post Test Mean Score of Stress in Experimental Group and Clinical Characteristics of Patients Admitted in ICU. $n=100$

\begin{tabular}{|c|c|c|c|c|c|}
\hline Clinical Characteristics & $\mathbf{N}$ & Mean & SD & Stat Results & Significance \\
\hline $\begin{array}{ll}\text { Diagnosis on admission } \\
\text { - } & \text { Surgery } \\
\text { - } & \text { Trauma / orthopedic }\end{array}$ & $\begin{array}{l}14 \\
86 \\
\end{array}$ & $\begin{array}{l}33.60 \\
38.94 \\
\end{array}$ & $\begin{array}{l}5.72 \\
7.56 \\
\end{array}$ & $\begin{array}{c}\mathrm{t} \text { value } \\
2.604\end{array}$ & $\mathrm{P}<0.05 * * *$ \\
\hline $\begin{array}{l}\text { Other illness } \\
\bullet \quad \text { Yes } \\
\text { - } \quad \text { No } \\
\end{array}$ & $\begin{array}{l}14 \\
86 \\
\end{array}$ & $\begin{array}{l}33.60 \\
38.94 \\
\end{array}$ & $\begin{array}{l}5.72 \\
7.56 \\
\end{array}$ & & $\mathrm{P}<0.05 * * *$ \\
\hline $\begin{array}{l}\text { No. of medicines } \\
3 \\
4 \\
5 \\
5\end{array}$ & $\begin{array}{c}9 \\
17 \\
17 \\
57\end{array}$ & $\begin{array}{l}36.45 \\
33.26 \\
43.90 \\
37.96 \\
\end{array}$ & $\begin{array}{l}7.52 \\
5.47 \\
5.59 \\
7.53 \\
\end{array}$ & $\begin{array}{c}\text { F Ratio } \\
7.461\end{array}$ & $\mathrm{P}<0.05^{* * *}$ \\
\hline \begin{tabular}{ll}
\multicolumn{2}{l}{ Respiratory rate } \\
$\bullet$ & Normal \\
$\bullet$ & Deviated
\end{tabular} & $\begin{array}{l}11 \\
89 \\
\end{array}$ & $\begin{array}{l}42.53 \\
37.54 \\
\end{array}$ & $\begin{array}{l}7.75 \\
7.35 \\
\end{array}$ & $\begin{array}{c}\mathrm{t} \text { value } \\
2.190 \\
\end{array}$ & $\mathrm{P}<0.05 * * *$ \\
\hline
\end{tabular}




\begin{tabular}{|l|c|c|c|c|c|}
\hline $\begin{array}{l}\text { Visual Analogue score } \quad \text { Low pain } \\
-\quad \text { High pain }\end{array}$ & 29 & 34.846 & 5.960 & $\mathrm{t}$ value & $\mathrm{P}<0.05^{* * *}$ \\
\hline$\quad 71$ & 39.493 & 7.737 & 2.899 & \\
\hline $\begin{array}{l}\text { Length of ICU stress } \\
>5 \text { days }\end{array}$ & & & & & \\
$<5$ days & 81 & 37.428 & 7.129 & $\mathrm{t}$ value & $\mathrm{P}<0.05^{* * *}$ \\
& 19 & 41.206 & 8.640 & 1.995 & \\
\hline No. of hospitalization & & & & & \\
Experience & & & & $\mathrm{P}<0.05^{* * *}$ \\
Once & 29 & 35.325 & 6.85 & $\mathrm{t}$ value & \\
twice & 71 & 39.297 & 7.54 & 2.450 & \\
\hline
\end{tabular}

$\mathrm{P}<0.05 * * *$

It is inferred that there is a association between post test mean score of ICU stress in experimental group with the clinical characteristics such as diagnosis on admission, other illness, number of medication, respiratory rate, visual analogue score, length of ICU study and number of hospitalization experience.

\section{DISCUSSIONS}

The first objective is to determine the contributing factors for ICU stress

The results revealed that the mean score of interpersonal factors in both the experimental and control groups are higher than the intra personal and extra personal factors. The researcher concluded that the environmental factors such as observing treatment that are administered to other patients, missing the spouse, Men and women in the same room, not receive adequate explanation about the treatment and procedure etc.

The above finding was supported by the study done by syen-Tore and Frederickson who identify the stressors experienced by the ICU patients were in three ways which includes related to body, related to room and relationship (stress reaction, being alone, lack of privacy, missing of spouse or partners)

The second objective of the study is to assess the pre test and post test level of stress in experimental and control group.

The pre test level of stress in experimental (54\%) and control group (51\%) samples have high level of stress. However in post test $49 \%$ of samples in experimental group found to have low level stress and nobody found to have high level stress. In control group post test $48 \%$ samples found to have high level stress. The above findings configured with the research study of Balasubramaniyan. The findings revealed that majority of the samples had high level of anxiety (42\%) in ICU.

The third objective is to evaluate the effectiveness of intervention package in ICU stress. The findings indicate that the overall post test mean score of stress in experimental group is $38.14(\mathrm{SD}=7.54)$ and the overall pre test mean score is $66.30(\mathrm{SD}=4.95)$ which is statistically significant at 0.001 level $(\mathrm{t}=28.863 \mathrm{P}<0.001)^{* * * *}$

It is also statistically proved that there is difference between the experimental and control group post test scores of various dimensions of stress namely physical factors $(\mathrm{t}=14.21 \mathrm{P}<0.05)$, psychological factors $(\mathrm{t}=41.92 \mathrm{P}<0.05)$ and social factors $(\mathrm{t}=7.87 \mathrm{P}<0.05)$.

The researcher concludes that psychoacoustic, and tactile touch therapy reduce the physical, psychological and social factors related to stress in the experimental group. Ross Adams et.al conducted the study to evaluate the 
effectiveness of massage therapy on pain, relaxation, emotion, sleep and recovery. After massage the post test mean pain score was reduced than mean pre test mean score which improve the emotional well being, sleep of the samples.

The fourth objective is to find out the association between post test level of stress in experimental group with the clinical characteristics. It is inferred that there is an association between post test mean score of ICU stress in experimental group with the selected clinical characteristics of patients such as diagnosis on admission $(t=2.604 \mathrm{P}<0.05)$ other illness $(\mathrm{t}=2.604 \mathrm{P}<0.05)$ number of medications $(\mathrm{F}$ ration $7.461 \mathrm{P}<0.05)$ respiration rate $(\mathrm{t}=2.190 \mathrm{P}<0.05)$ visual analogue score $(\mathrm{t}=2.899 \mathrm{P}<0.05)$ length of ICU stay $(\mathrm{t}=1.995 \mathrm{P}<0.05)$ and number of hospitalization experience $(\mathrm{t}=2.45 \mathrm{P}<0.05)$.

These findings are supported by carina Aparaecida et.al who conducted the descriptive study to identify the association between stressors with socio demographic and clinical characteristics of patients in Intensive Care Unit. Stressors were associated with female gender, the samples without previous hospitalization. Etc....

\section{Implications of the Study}

\section{Nursing Practice}

The study reveals the fundamental responsibility of the ICU nurse (ie) is to support the patent on various domains such as physical, psychological and social which will hard to minimize distress.

\section{Nursing Education}

Nursing curriculum should emphasize not only the physical domains of the patients in ICU but more on the psychological domain which could be achieved through appropriate environmental assessment in the ICU.

\section{Nursing Administration}

- Nursing administrators can collaborate with the nursing researchers to conduct further research in utilization of complementary and alternative therapies.

- Short term certification course on complementary and alternative therapy could be arranged for nurses to uplift their knowledge and practical skill

\section{Nursing Research}

Nurse researcher should disseminate the research finding which help the future researcher to build upon and motivate other researcher to conduct further studies.

\section{CONCLUSIONS}

Evidence of present study suggested that ICU experience could be the stressful environment to the patient admitted in ICU. It is the role and functions of the critical care nurses to perform comprehensive assessment on contributing factors for stress in ICU clients. Routine ICU treatments have its benefits over the physical need of the clients but not the psychological, psycho social needs of the patients. The study finding has offered statistical evidence regarding the benefits of psychoacoustic therapy and touch therapy.

\section{REFERENCES}

1. Honkus(2003). Sleep deprivation in critical care unit crit care nurse; 26(3): 179-189 
2. Roger Ulrich, Craig Zimring, Xiaoboevan, Anjali Joseph(2004). Role of Physical environment in the hospital of $21^{\text {st }}$ century. The centre for health design(online).; Available from :http//:www.healthdesign.org (Accessed on 2012 Dec.28)

3. Fredrickson, Ring berg(2007). Living the situation, stress experiences among intensive care patients. Intensive care critical nursing:; 23(3):124-31

4. Hofhusis(2010). Experiences of critically ill patients in ICU. Journal of Intensive crit care nurse.; 24(5) :300-13

5. Daniel J. Lamas(2013). After the ICU. What does it mean to be okay? New Engand Journal of Medicines.; 11:1-4. 